\author{
Studies on the Testing Methods of the Thyrold Function and their \\ Application to Clinical Tests in Leprosy Patients \\ ITSUO YAGI*, YoSHIKo OSAWA, \\ SADAE TSUTSUMI, YoshIKI SAKAMOTO and KAZUAKI NAKAMURA \\ (National Institute for Leprosy Research)
}

Although the thyroid functions of leprosy patients had already been studied by several clinicians or researchers, there had been no agreement as to whether the function is accelerated or damaged by leprosy, nor whether the function is at all related to the process of the symptoms in leprosy.

In conjunction with these points, in the first stage, the authors proposed to examine the several methods of testing the thyroid function which were more esteemed than that of measuring the PBI, for the puropose of applying them to examine the problems in leprosy.

In regard to Hamolsky's method, it was found that the uptake of ${ }^{131}$ I-triiodothyronine $\left.{ }^{131} \mathrm{I}_{-} \mathrm{T}_{3}\right)$ by red blood cells should be corrected by measuring the hemoglobin together with the radioactivity, both of which had been eluted from the red blood cells during and before the routine work. This correction method based on the principle that both the ${ }^{131} \mathrm{I}-\mathrm{T}_{3}$ and the hemoglobin measured by the cyanmethoHb method were proportional to each other.

Next, a new type of sponge found by Dr. Inagaki of Tokyo Metropolitan Police Hospital was compared with resin sponge. The former consists of acetalized polyvinyl alcohol and is termed PVF. The latter is considered too expensive for tests wite a large number of patients in the routine work.

The results were as follows :

(1) When both the size of the sponge and the solution of ${ }^{131} \mathrm{I}-\mathrm{T}_{3}$ were correspondingly diminished, the uptake by the PVF was influenced much more than that by the resin sponge (RS).

(2) The binding of PVF to ${ }^{131} \mathrm{I}_{-} \mathrm{T}_{3}$ was somewhat more fragile than that of RS, because a considerable portion of ${ }^{131} \mathrm{I}_{-} \mathrm{T}_{3}$ taken up was eluted from the PVF, when the former sponge was again contacted with an unlabeled serum.

(3) PVF showed no marked inferiority to RS in the deviation of the uptake values. With a sponge termed new PVF, in which PVF was insereted, a somewhat remarkable deviation of the uptake values was found.

(4) When the same sponge was repeatedly employed in the test, the lowering of the uptake by the PVF was more rapid than that by the RS.

(5) The increase of the uptake by PVF with the addition of phenol of thiourea was similar to that by RS, though in the case of phenol, it was slightly more sensitive in

*(Presently the Salvation Army Kiyose Sanatorium) 
the latter.

(6) The influence of heparin could not be clearly detected in either of the sponges. However, in the case of a double oxalate added to a serum sample in the concentration of $1-36 \mathrm{mg} / \mathrm{ml}$, the uptake by the new PVF increased to a certain extent with the concentration of the anticoagulant, while that by RS was conversely decreased.

(7) The adsorption of $l \cdot{ }^{14} \mathrm{C}$-tyrosine of $l \cdot{ }^{14} \mathrm{C}(\mathrm{U})$-glutamic acid on both of the sponges was observed, especially in the RS, though the binding was fragile and showed no influence on the uptake.

(8) The proportionality of the uptake values of PVF and RS was certified by employment in tests on leprosy patients and those of hyper- or hypo- thyroidism, as well as on the healthy.

(9) PVF is much less expensive than RS and the serum necessary for one PVF is half the volume of thar for one RS.

Based on these results, it was concluded that PVF could be applied to the test of the thyroid function in leprosy patients as well as in the usual routine works.

Therefore, the authors examined the function of various type of 69 leprosy patients in comparison with that of 56 healthy persons and 14 tuberculosis patients by the use of PVF. It was found that, according as the process in leprosy, the uptake (\%) was gradually lowered, while no difference could be found in healthy persons and tuberculosis patients. In addition, the patients showing epithelioid cell reaction (ECR) tended to show a comparatively higher uptake in contrast with those during ENL, though not a large number of cases could be tested. If it can be presumed that the changes in the serum globulin components have no relation to the levels of TBG, the result indicates a tendency in itself to the thyroid function in leprosy patients. This finding coincided well with the results reported by Yagi, in whick a remarkable acceleration in the metabolism had been noticed in leprosy patients showing ECR. ECR is known to be a case in which a fairly abrupt transition from L- to T-type can be seen. Therefore, the result directs our attention to the significance of the thyroid hormones concerned with the healing mechanism of leprosy.

Moreover, it is supposed that peripheral changes can inhibit the oxidoreduction system which links the deiodination to the thyroid hormones. The provocation of ENL by inorganic iodides is well-known fact in leprosy. Yagi and Ohsawa had reported on the markedly lowered function in the adrenal cortex of leprosy patients just before the occurrence of ENL. In such a symptom, a lowering of the mechanism to suppress antibody formation and their general adaptation syndrome must be considered. If an inorganic iodide is administered to those patients, it may be likely to irritate the cells in the periphery tissues, or, in some cases, may bring about an unfavorable influence on the in vivo iodine balance (Wolff-Chaikoff effect).

On the other hand, Dr. Sasaki of this Institute also has reported on the severe amyloidosis characterized by amyloid goiter in several leprosy patients, diminshing the resissance to microbial infection or showing resistance to chemotherapy. Also, Dr. K. Kato 
reported on TBG lowered by the administration of a corticosterone.

Hereupon, considering the complicated factors lying between the thyroid function in leprosy patients and the clinical effects of antileprous agents, a discussion was developed for the improvement of chemotherapy in leprosy, especially for the significance of the various phenomena in the hormonal organs during the longterm clinical trial of antileprous agents. 


\title{
甲状腺機能検査法の研究とその患者における 臨床検査への応用
}

\author{
八木五夫* 大沢 佳子 \\ 堤貞衛坂本芳幹中村和明 \\ (国立多摩研究所)
}

（受付 昭和 45 年 2 月 3 日)

\begin{abstract}
緒言
らい患者と甲状腺機能ないしヨードとの関係について は, 宗内 ${ }^{1 a)}$ の病理学的研究あるいはその他二, 三の機能 的研究(1a)-db)があるほかは未だ系統的研究は見当らない。 しかし Danielssen 以来らいに対するヨードの特異な作 用については注目する者も多く2a-g)，特にヨードによる 反応誘発の現象は有名である。

さらに青木 ${ }^{2 \mathrm{a}, \mathrm{b}}$ )はヨードによる診断的意義として治ら い作用を主張しているが，投与量の微細な用法とその副 作用をおそれて一般化されない。しかしらい病変に対し てヨードが何らかの特異な作用を持つことは一般に注目 されている。

これを基礎代謝の報告から考察すると, Blum 以来 $\operatorname{Marras}^{3 \mathrm{a})}, \mathrm{Moraes}^{3 \mathrm{~b})}, \mathrm{Ross}^{3 \mathrm{C})}$, 井口 ${ }^{3 \mathrm{~d})}$, 武田 ${ }^{3 \mathrm{e})}$, 宇都 宮 $^{3 \mathrm{f})}$ ，八木 ${ }^{3 \mathrm{~g})}$, 清水 $\left.{ }^{3 \mathrm{~h}}\right)$ らの成績があるけれども，らいが 極めて 経過の長い慢性疾患でかつ年令分布も広範なた め, その多数症例による集計的成績からは結論的意味づ けが困難であるのは否めない。ところが各病型ごとに長 期観察をおこなった八木の報告いによると， L 型， T型 ともに反応期でなければいつの場合もその基礎代謝は低 く，反応期ではいずれの場合 (ENL, Epithelioid Cell Reaction および acute Schub) も高くなることを報告 している。さてここで興味ある事実は ENL の著るしい 基礎代謝六進は発症後の短い一定期間であり, それを過 ぎるとにわかに低下の傾向を示し，その経過が長引けば たとえ高熱であっても著るしい低下が示されるのに反し て,治癋傾向の強い Epithelioid Cell Reaction (E.C.R.) では，その長い期間中の全経過にわたって著るしい基礎 代謝の亢進をつづけて治瘉傾向に至ることを明らかにし ていることである。すなわち治疮傾向の少い症例では,
\end{abstract}

\footnotetext{
* 現在救世軍清心療養園
}

いずれの場合も基礎代謝低下傾向が強いのに反して，ら いの一つの治忿機転である E.C.R. においてのみ有意の 基礎代謝の克進が存することを明らかにしている。もし 定説のごとく，基礎代謝穴進を甲状腺機能の元進と見る ことが許される前提において, その推論が許されるなら ば，らいの治癒機転において甲状腺機能の占める位置は 大きい。かかるヨードならびに基礎代謝に関する実験成 績から, 我々はらいにおいて甲状腺機能を究明する意味 の存することを認め, PBI 法に勝る簡便かつ安定な甲状 腺機能測定法の確立とその臨床的応用を志して本研究を 開始した。たまたま稲垣引は多数症例を検查するには高 価に過ぎるレヂンスポンヂに代ってより安価なスポンヂ による甲状腺機能検查法を報告した。それゆえ著者らは まず当測定法を検討報告した。ついで我々は当該測定法 に主体を置いて全般的に甲状腺機能測定法を検討し, そ の結果を患者における当該機能測定に活用せんとした。

\section{実験方法}

I . 甲状腺機能測定法の基礎的検討

1）赤血球法：Hamolsky ${ }^{(6-c)}$ の方法に従い，抗凝固 剤の影響, 溶血にともなう ${ }^{131}$ I-Triiodothyronine $\left.{ }^{131}{ }^{13}-\mathrm{T}_{3}\right)$ 赤血球摂取率低下の補正法を検討した。

2) Resin-Sponge 法: $\mathrm{T}_{3}$ Diagnostic Kit Triosorb (RS，ダイナボット研）を用い, 血清, RS 使用量節約, 同一 RS を反覆使用した場合の $\mathrm{T}_{3}$ 摂取率低下の状況, 抗凝固剤や血清蛋白変性剤の影響を検討した。

3） PVF-Sponge 法: 稲垣 5 の方法に従い白色棒状の Acetalized polyvinyl alcohol を切断, 各切片の一定重 量あたりの ${ }^{131} \mathrm{I}-\mathrm{T}_{3}$ 捸取率を常に併記検討した。通常 PVF は125 135mg の切片を用い, 一方 RS は通常 $60 \pm 5 \mathrm{mg}$ であった。

4） ${ }^{131} \mathrm{I}-\mathrm{T}_{3}$ 摂取率に関する PVF と RS の比例性 
の検討 : 正常人, らい患者, 甲状腺機能六進または低下 症例の各血清試料を両スポンヂで測定比較。一部の試料 には131I-Thyroxine（131I-T 4 ）を使用した。

III．スポンヂ法によるらい患者甲状腺機能の測定 PVF により69例の種々の病型の患者，56例の健常人， 14例の結核患者につき検査し，その結果を比較した。

I . II . を通じて血清に ${ }^{131}$ I- $\mathrm{T}_{3}$ 溶液を添加，その混液 にスポンヂを浸漬後スポンヂの水洗開始に至るまでの $25^{\circ} \mathrm{C}$ における培盖所要時間の長短が 捸取率に影響する 大なる要因であることを認めたので，必要に応じて対照 試料を置き，また培養時間を厳守しうるよう試料の回転 をエ夫した。

\section{実験結果}

${ }^{131} \mathrm{I}-\mathrm{T}_{3}$ の純度について: $\mathrm{T}_{3}$ は $\mathrm{T}_{4}$ に比して血清蛋白 結合強度が弱い。そのため市販の $\mathrm{T}_{4}$ に含まれる3, $5,3^{\prime}$ $\mathrm{T}_{3}$ (平均 $3.7 \%$ ）と $3,3^{\prime}, 5^{\prime}-\mathrm{T}_{3}$ (平均 $5.4 \%$ ） が 原因して T4の蛋白結合率を見かけ上低下させるという報告汭， 紫外線照射で ${ }^{131} \mathrm{I}-\mathrm{T}_{4}$ がヨード化サイロニン類へ脱ヨー ドした報告てbなどが散見される。そこで入手後 1 週間お よびなお 4 週間水室中放置した ${ }^{131} \mathrm{I}^{-} \mathrm{T}_{4}$ をそれぞれ像 1 $\mathrm{A}, \mathrm{B}$ 展開系で $\mathrm{PPC}$ 上昇, $1 \mathrm{~cm}$ 巾に展開部を截切し， 濾紙中放射能測定，対照 $\mathrm{T}_{3}$ の硫酸セリウム法 ${ }^{7 \mathrm{c})}$ による 発色スポットと比較したところ, 主放射能ピークは一致 したが，ほかに若干の小ピークを認めた。入手後 1 週お よび 5 週の ${ }^{131} \mathrm{I}-\mathrm{T}_{3}$ のB展開濾紙を富士X線フィルム $\mathrm{KX}$ に各 1 週間および 2 週間露出したところ像 $1 \mathrm{C}, \mathrm{D}$ のように入手後経時すると ${ }^{131} \mathrm{I}^{-} \mathrm{T}_{3}$ による黒化部位が著 るしく減衰しているに反し，その上下の不純物と考えら れる黒化部位は 4 週のものが 1 週のものと同等程度に感 光し，不純物含有率の増大を思わしめた。それゆえ 131I-T 3 は入手後直ちに使用した。

I . 甲状腺機能測定法の基礎的検討

1）赤血球法：40\%蓚酸カリウムを抗凝固剂仁用いた 直後血を Hamolsky 法に従い生塩水 $10 \mathrm{ml}$ で 4 回洗滌, 各遠沈上澄中放射能が自然計数率の何倍かを右縦軸に， 各上澄中血色素量をシアンメトへモグロビン法で測定し た吸光度を左綻軸にとり像 2 (a) に示した。それに較心 て採血後 5 日の血液では像 $2(\mathrm{~b})$ のように著るしい溶血 が見られ， 3 回以後の洗沙上澄にも洗涤にともない血色 素溶出が見られ，赤血球腺の脆弱化が思われた。しかし 上澄中放射能は初回上澄中に圧倒的に多いので，それ之 溶出血色素との関係は求められなかった。

そこで $40 \%$ 苳酸カリウム, 二重荫酸塩, ヘパリンのい
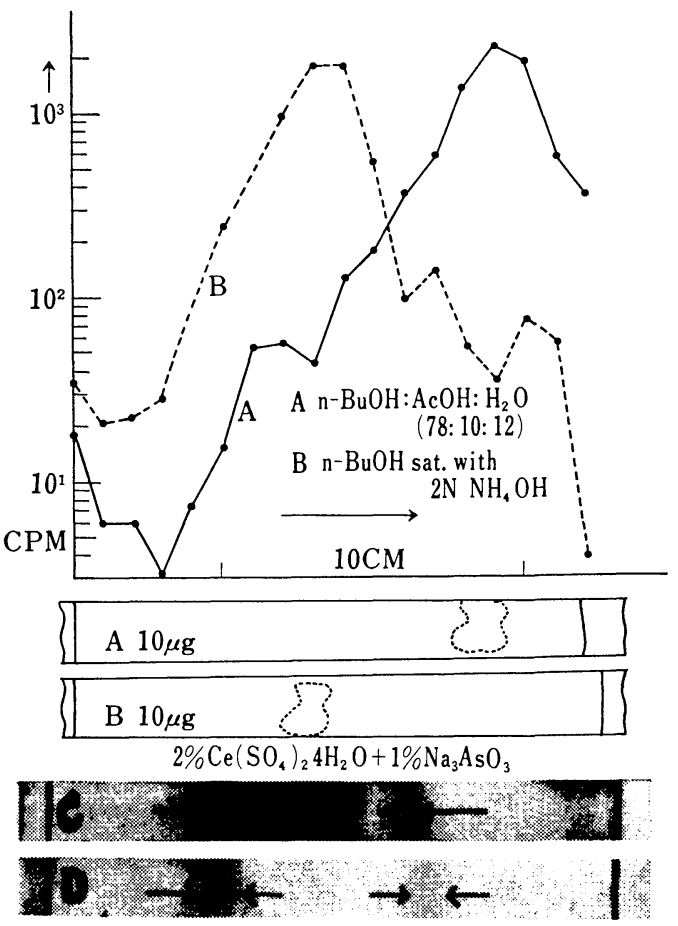

Fig. 1 Increase of Impure Substances in Coomercial Triiodothyronine (131 $\left.\mathrm{I}_{-} \mathrm{T}_{3}\right)$ during the Preservation for 4 Weeks

C : ${ }^{131} \mathrm{I}-\mathrm{T}_{3}$ at $1 \mathrm{~W}$ after the assay

$\mathrm{D}:{ }^{131} \mathrm{I}-\mathrm{T}_{3}$ at $5 \mathrm{~W}$ after the assay

Radioativity: Measured by a low-back sample changer, Aloka SC-5

Detection of spots : Spraying of $2 \% \mathrm{Ce}\left(\mathrm{SO}_{4}\right)_{2}$ $\mathrm{H}_{2} \mathrm{O}$ and $1 \% \mathrm{Na}_{3} \mathrm{AsO}_{3}$

Radioautography: Contacted with a film, Fuji X-ray film Kx

ずれかを抗凝固剤にした 20 例の人血を0.6，0.45各\%食 塩水で部分溶血させ，像 3 のように溶出放射能と溶出血 色素吸光度とをそれぞれ綐軸，横軸にとりその関係を求 めたところほぼ比例関倸が存するのを認めた。それゆえ 赤血球の ${ }^{131}$ - $T_{3}$ 摂取率を 測定する際には，洗滌にとも なら溶出血色素長を累計し，その対応放射能值を洗深済 赤血球の見かけの摂取放射能值に加算する心゙きである。 なおへマトクリット值が38以下では摂取率そのものの低 下に影響するという報告7d)，当該摂取は直接的な active transport ではないが，幼若赤血球は成熟赤血球に較心゙ て摂取率が高く，阻害剂の影響も受けやすいという報告 がある7e)。これら血球の状態に影響される以外に，多数 試料の場合は洗沙労作が甚だしく既に古典化した方法と して実用性に欠けていた。なお多数の試料に立脚してい 

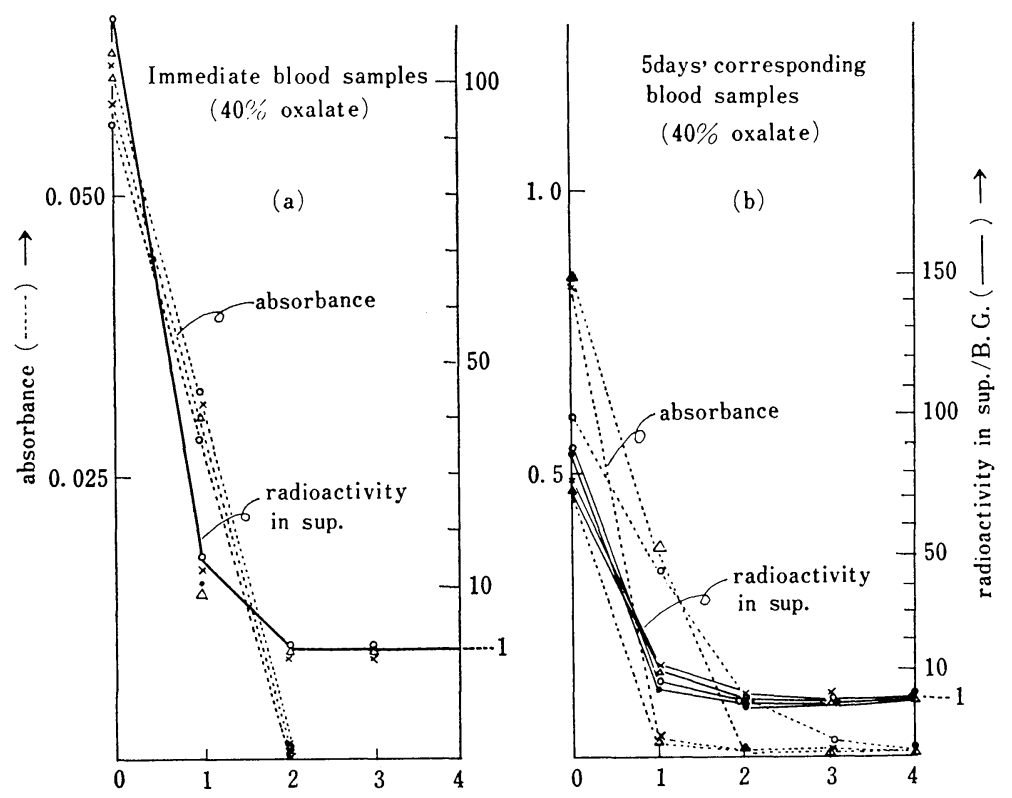

Fig. 2 (a, b) Radioactivity and Hemoglobin Content in the Supernatante of Precipitated Red Blood Cells Administered with Hamolsky's Method

$\mathrm{Hb}$ : Measured by cyanmetho-Hb method

Radioactivity: Measured by a well-type scintillation counter, Aloka PS-9

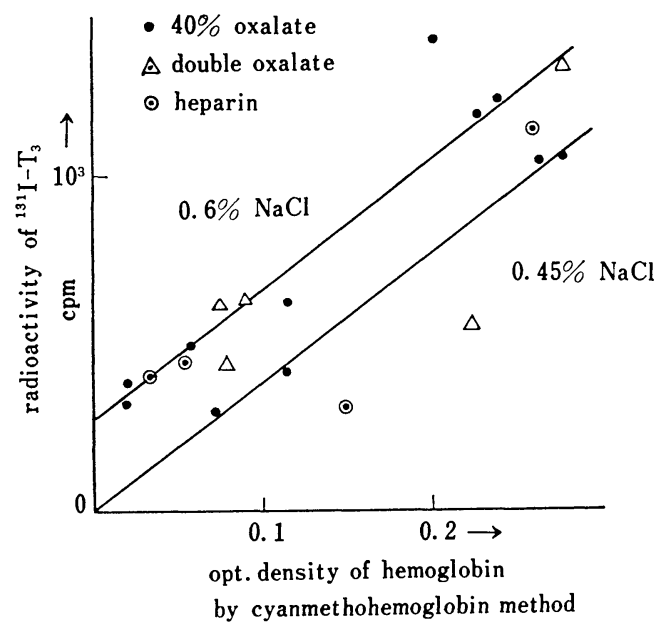

Fig. 3 Proportional Relation between 131 I$\mathrm{T}_{3}$ and $\mathrm{Hb}$ Eluted from the Hemolyzed Red Blood Cells after Labeling with ${ }^{131} \mathrm{I} ; \mathrm{T}_{3}$

る訳ではないが，同一条件で比較した際にらい患者試料 は溶血が著るしかった。

2 4) RS と PVF の比較：像 $4(\mathrm{~b}, \mathrm{c})$. は各スポン ヂを $2 / 3,1 / 2,1 / 3$ に切断し, そのスケールで血清, ${ }^{131}-\mathrm{T}_{3}$ 所要量を節約した場合の摂取率 (実線) とスポンヂ $10 \mathrm{mg}$
当りの放射能 (点線)の各平均值を示す。 $\mathrm{RS}$ は 1 コのま まの場合血清, ${ }^{131} \mathrm{I}-\mathrm{T}_{3}$ の50\%プロピレングリコール (P. G.) 溶液 (Triomet) 各 $1 \mathrm{ml}$ を要するし，当該溶液に は何らかの安定剤が混入されているようである。PVF 1 コのままでは血清と $0.1 \mu \mathrm{Ci}{ }^{131} \mathrm{I}-\mathrm{T}_{3} / 0.5 \mathrm{ml}$ 生塩水各 $0.5 \mathrm{ml}$ を要するのみである。像 4 (a) は血清を添加せ ず，代りにその量だけ媒質を添加した際の PVF 摂取率 を示した。すなわち $50 \%$ P.G を媒質とすると血清添加 時は摂取率が高まるが, 血清無添加の場合は媒質の影響 は少なかった。血清量, 試液量の節約にともないPVF では $2 / 3$ 籄以下で摂取率減少が見られるが，RS では規 則的変動といらよりはスポンヂが正確に切断しにくいた めの不正確に原因する変動と考えられる。なぜならば10 $\mathrm{mg}$ 当りの摂取放射能は RS では $1 コ ， 1 / 3$ コで差はほ とんぞ無い。それゆえ高価な RS は其礎実験では目的 に応じて半切使用した。

稻垣ら帛は $\mathrm{PVF}$ の種々改良を試み, PVF をほかの 基剤ではさんだ PVFを試作した。しかしこの試作品 (new PVF と仮称) は, 同一血清で PVF, RS と比較 すると像 5 のように測定值のばらつきがやや目立ち, 捸 取率の微小差異を求める実験では使用を避けた。

これら有機樹脂製スポンヂとイオン交換樹脂製の RS 


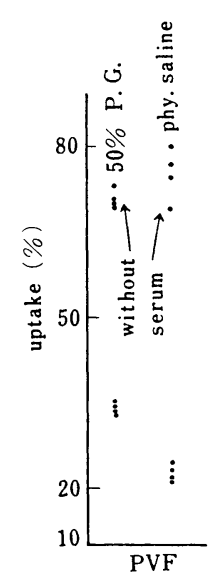

(a)

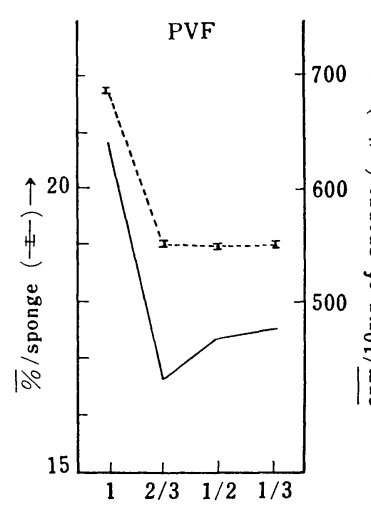

(b)

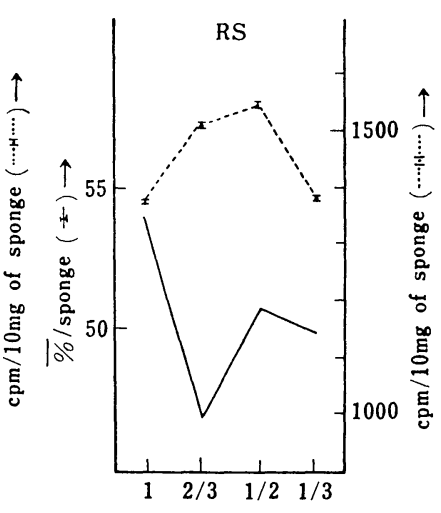

(c)

Fig. 4 (a-c) Influence of Basal Media (a). or That of the Size of Sponges (b, c). upon the Uptake of ${ }^{131} \mathrm{I}_{-} \mathrm{T}_{3}$

RS : Abbreviation of Resin Sponge, $T_{3}$ Diagnostic Kit Triosorb

PVF : A sponge consisted of acetalized polyvinyl alcohol. When a sponge was halved, the volume of ${ }^{131} \mathrm{I}_{-} \mathrm{T}_{3}$ solution was also halved.

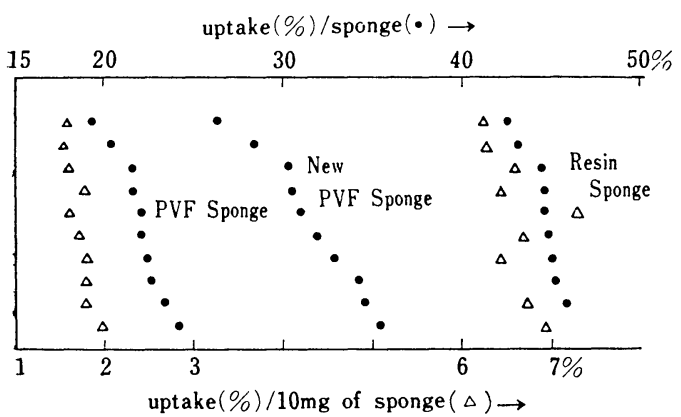

Fig. 5 Comparison of Several Kinds of Sponges in the Accuracy of ${ }^{131} \mathrm{I}_{-}-\mathrm{T}_{3}$ Uptake (\%)

Serum: A sample of healthy new PVF: A sponge, in which PVF in inserted

との ${ }^{131}$ - $T_{3}$ 結合強度を比較するため，像 6 黒丸印のよ うに一度血清無添加で摂取させたスポンヂを ${ }^{131}$-T 8 を 含まない血清で再培養したところ, new PVF では著る しく，RS ではそれよりやや低い ${ }^{131} I-T_{3}$ の溶出を見た。 次に血清添加のもとに摂取させたスポンヂを同様に標識 しない血清で再培養したところ, new PVF ではやはり 著明な ${ }^{131} \mathrm{I}-\mathrm{T}_{3}$ の溶出を見たが RS では既に血清ととも に掼取された場合はほとんど溶出しなかった。これらは RSの方が new PVFよりも ${ }^{131} \mathrm{I}_{-} \mathrm{T}_{3}$ との結合強度が強 いことを意味するが，しかし血清添加の場合は，その水

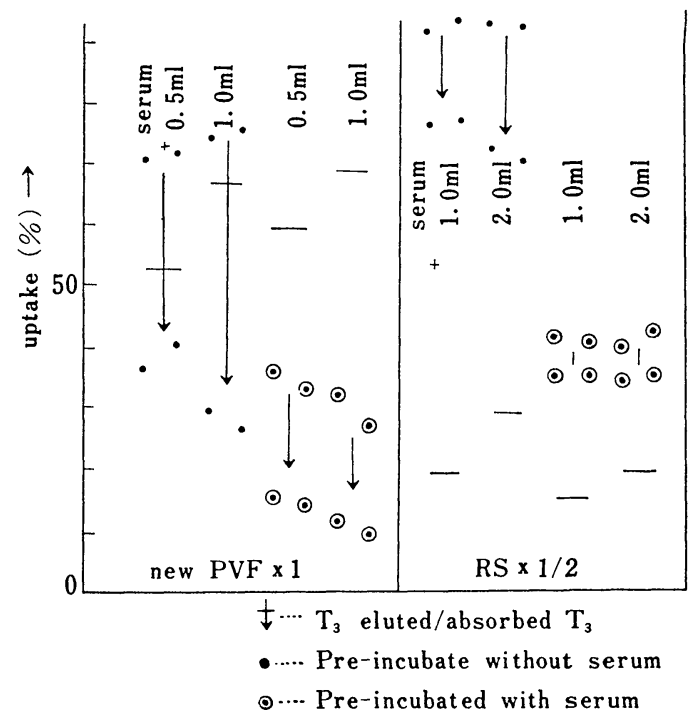

Fig. 6 Elution of Uptaked ${ }^{131}$ I-T $_{3}$ from new PVF or RS after Re-contact with Non-labeled Serum

$\mathrm{RS} \times 1 / 2$ : Halved Resin Sponge

洗によって PVF 摂取率が影響されることは皆無で, 数 分間水洗しても摂取放射能の変化は見られなかった。

次に同一スポンヂを反復使用した際の摂取率低下現象 を検討した。像 $7(\mathrm{a}, \mathrm{b})$. は血清添加または無添加で 4 回0.1 $\mu \mathrm{Ci}{ }^{131} \mathrm{I}-\mathrm{T}_{3}$ で反覆使用し(各太実線, 太点線), あ るいは毎回 $0.025 \mu \mathrm{Ci}$ ずつ延 4 回で計 $0.1 \mu \mathrm{Ci}$ の ${ }^{131} \mathrm{I}-\mathrm{T}_{3}$ 


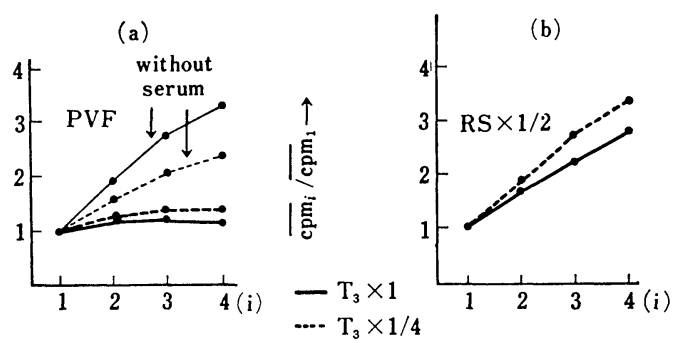

(c)

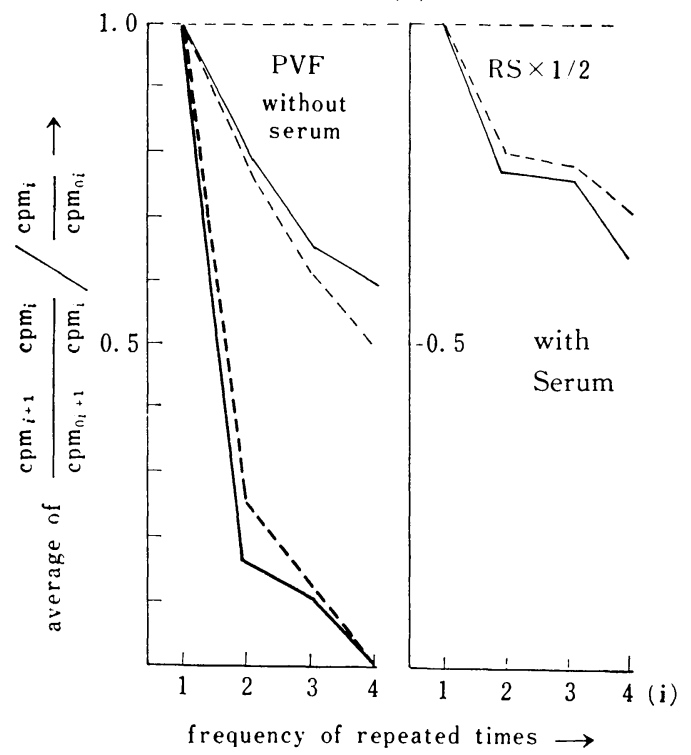

Fig. 7 (a-c) Comparison between PVF and RS in Their Saturation by ${ }^{131} \mathrm{I}$ $\mathrm{T}_{3}$ with or without Serum when repeatedly Employed

Fine lines mean the administration of the sponges without serum.

$\mathrm{T}_{3} \times 1: 1 \mathrm{ml}$ of Triomet in the case of $\mathrm{RS}$, $0.1 \mu \mathrm{Ci}$ of ${ }^{131} \mathrm{I}_{-} \mathrm{T}_{3} / 0.5 \mathrm{ml}$ (phy. saline) in the case of PVF in each contact

$T_{3} \times 1 / 4$ : Thus, $T_{3} \times 1$ was used throughout the four times of repeated contact (dotted lines).

$\mathrm{cpm}_{\mathrm{i}}$ : Radioactivity in a sponge after the employment of $\mathrm{i}$ times

cpmoi: Total radioactivity in a sponge and the added ${ }^{131}{ }^{1}-\mathrm{T}_{3}$ solution after the employment of $\mathrm{i}$ times

$\mathrm{cpm}_{\mathrm{i}+1}-\mathrm{cpm}_{\mathbf{i}} / \mathrm{cpmoi}_{+1}-\mathrm{cpm}_{\mathrm{i}} / \mathrm{cpm}_{1} / \mathrm{cpmol}$ : It means the real increase of uptake (\%) in each contact divided by the first uptake ( $\%)$

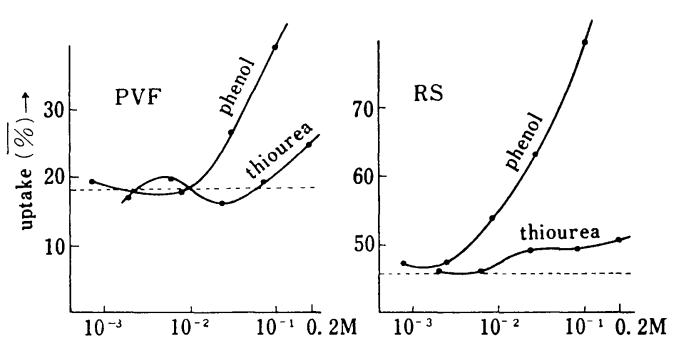

Fig. 8 Increase of ${ }^{131} \mathrm{I}_{-} \mathrm{T}_{3}$ Uptake by PVF or RS, When Added some Denaturants to Serum

Each dotted line means the average of uptake (\%) by PVF or RS administered without the denaturants.

を血清添加または無添加 (各細実線, 細点線)で攝取させ た場合のスポンヂ摂取放射能の増加推移を示す。RS で は血清添加の場合でも摂取は飽和に至らず，延 $4 \mu \mathrm{Ci}$ 摂取させても僅かに延 $1 \mu \mathrm{Ci}$ 摂取例より低下が見られる 程度であるに反し，PVF では血清添加の場合は初回で ほとんど飽和し，次回からの新らたな摂取は僅小であっ た。それを毎回の真の摂取率で表現したのが像 7 (c) で RS に較べて PVF の飽和が早いことが明らかであ る。一方血清無添加の場合は PVF の捸取率はほぼ直線 的に低下し, その際 ${ }^{131} \mathrm{I}-\mathrm{T}_{3}$ の延添加量で差が認められ ないのは生塩水も老化を早めることを思わせる。

蛋白変性剤を加えれば Thyroxine Bound Protein (TBP) Albumin 双方が変性するので 131I-T 結合部位 が減じ遊離 131 I-T 3 が増すから摂取率は大になる。その 結果を像 8 に示した。

像 8 で石炭酸の影響索受ける度合はPVF の方がやや 鈍感なように見受けられる。

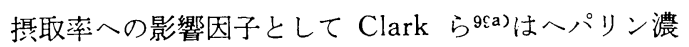
度上昇につれ RS 粉末状樹脂の場合は最低值を有する 下凸曲線を示すと報じた。これらはへパリンの蛋白結合 部位 ${ }^{9 \mathrm{~b})}$ と照合する時に興味深い。著者らも追試したとこ ろ, PVF では $3 \sim(1250)^{-1} \times 1.66 \mathrm{mg} / \mathrm{ml}$ のへパリン濃 度で $3 \mathrm{mg} / \mathrm{ml}$ でやや低值を見た以外は影響を認めず, $\mathrm{RS}$ では $3 \sim 1 \times 1.66 \mathrm{mg} / \mathrm{ml}$ ではむしろ高值で $(250)^{-1} \times$ $1.66 \mathrm{mg} / \mathrm{ml}$ を谷とした下凸曲線を示したがそれほど明 瞭ではなかった。次に血清 $1 \mathrm{ml}$ 当り $1 ， 6 ， 36 \mathrm{mg} に$ 二重蓚酸を加えて影響を見たところ RS では平均 38.4 , $37.5,34.8 \%$ と漸減, new PVF では $31.3,33.6,35.6$ \%と逆に漸増した。

さて血中に遊離アミノ酸が存在する以上は,これが捸 取率に影響するか否かは興味深いので, 化学構造が $\mathrm{T}_{3}$ 


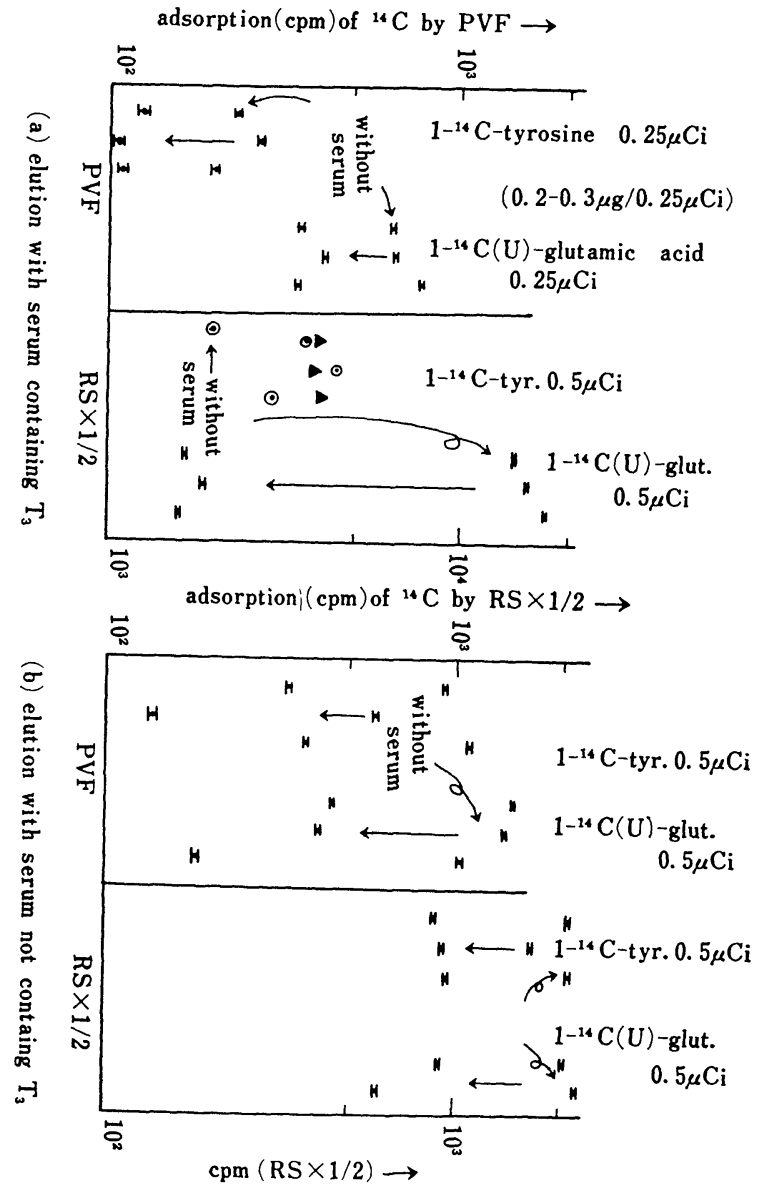

Fig. 9 (a, b) Elution of ${ }^{14}$ C-labeled Amino Acids from the Sponges by the Re-contact with the Serum Samples Contained or not Contained $\mathrm{T}_{3}$, after Contact with the Basal Media Labeled with ${ }^{14} \mathrm{C}$-Amino Acids

Radioactivity: Measured by Packard Tri-Carb Liquid Scintillation Counter Model 314 AX, suspending the sponges in a dioxane-type scintillator

と類縁のあるチロヂンと赤血球への取込が少く9c), 血清 中に残余すると考えられたグルタミン酸を選び検討した

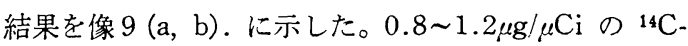
標識チロギン塩酸塩またはグルタミン酸ナトリウムを $0.25 \sim 0.5 \mu \mathrm{Ci}$ 宛 $\mathrm{T}_{3}$ 含有または不含生塩水または $50 \%$ P.G. $0.5 \mathrm{ml}$ に溶解, 当媒質 $0.5 \mathrm{ml}$ を混じスポンヂを浸 漬、 $25^{\circ} \mathrm{C} 1$ 時間培養後一旦スポンヂを洗滌，ヂオキサ

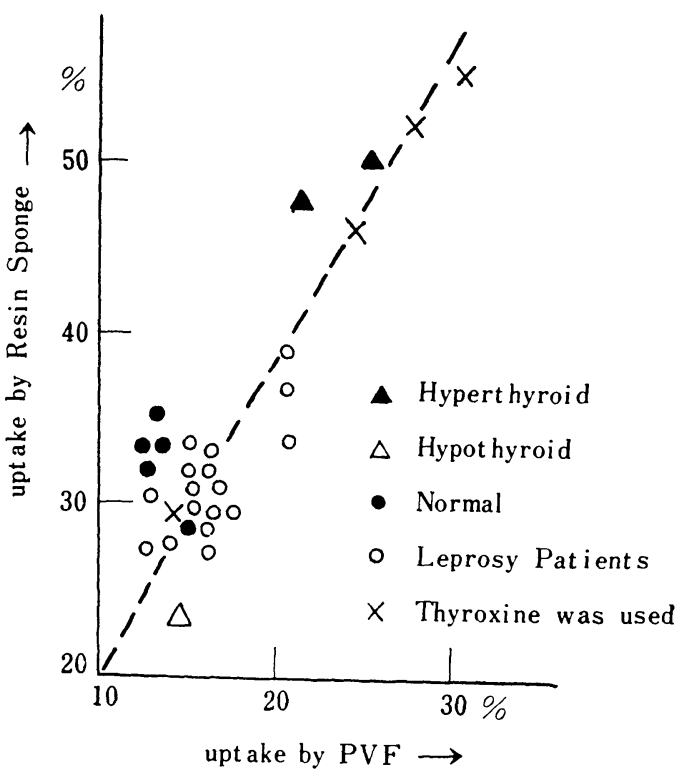

Fig. 10 Proportionality between PVF and $\mathrm{RS}$ in Uptake of ${ }^{131} \mathrm{I}-\mathrm{T}_{3}$

ン系シンチレーターに浮遊し放射能を測定, 別のスポン ヂを同様培養後無標識 $T_{3}$ 添加または不添加の血清と再 培養後同様にその放射能を測定した。その結果像 9 (a, b）のように，大略の傾向として RS はグルタミン酸を 良く吸着したが血清添加で溶出が著るしく，チロヂン はやや溶出が少いようであり，PVF では両アミノ酸と も溶出した。RS の方がやや吸着が強いようだが，いず れにせよ $\mathrm{T}_{3}$ とアミノ酸が一諸に摂取されることが認め られた。そこで逆に $\mathrm{T}_{3}$ を標識, アミノ酸を無標識にし て同様実験したところ, 両スポンヂで高濃度チロヂンの 場合に高值を見たが，それはチロヂン溶解のため添加し た塩酸の影響と思われ，グルタミン酸では $0.5 M$ の高濃 度で PVF のみの搨取率低下を見たが，それ以外では影 響を見なかった。これらから血清中アミノ酸は常にスポ ンヂに吸着されているが, 通常濃度では摄取率に影響し ないと考えられる。なお RS はシンチレーター中で漸 次分断し，PVF は透明膨潤化した。

以上を見ると PVF は RS に較べて ${ }^{131} \mathrm{I}^{-T_{3}}$ との結合 が脆く, 飽和しやすく, 摂取率レベルが低いので計数時 間がややかかり, 水洗回数もやや大であるが, 反面安価 であり, 所要血清量が $\mathrm{RS}$ の半分 $(0.5 \mathrm{ml})$ で済むし, 測定値ばらつきの点でもあながち劣るとは思われなかっ たのみか, 像10のように, RS との摂取率に関する比例 性が明瞭に認められた。 


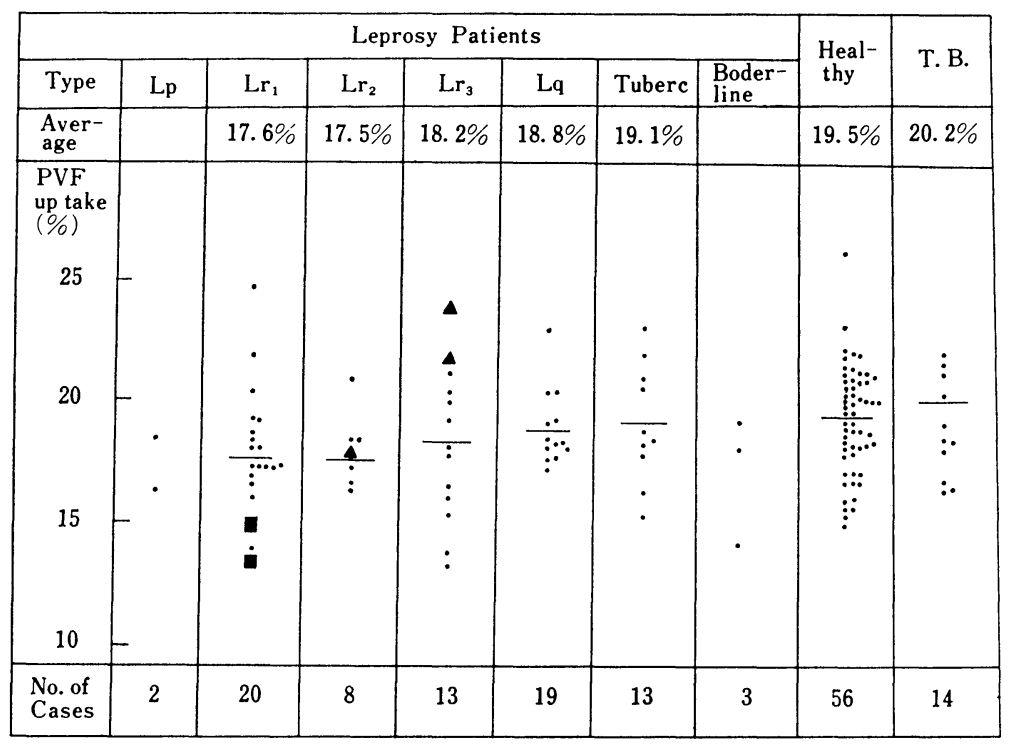

Fig. 11 Thyroid Function of Various Types of Leprosy Patients in Comparison with That of Tuberculous Patients or Healthy Tested by PVF

Black triangles: Patients during Epitheloid reaction

Black squares: Patients during ENL

像10で一部には ${ }^{131} \mathrm{I}_{\text {- }}$ 4 が用いられた。 $\mathrm{T}_{4}$ は $\mathrm{T}_{3}$ に 比してスポンヂ, 血清双方への結合が強くかつ摂取率は 高值を示す。しかし通常試料中には遊離 $\mathrm{T}_{4}$ はほとんど 含まれないので， ${ }^{131} \mathrm{I}-\mathrm{T}_{3}$ 搨取率への影響はほとんど無 いが, 遊離 T 4 を添加した血清では当該捸取率は影響さ れる7d)。

II．スポンヂ法によるらい患者甲状腺機能の測定

これら基礎研究資料を活用して種々の病型のらい患者 多数の結果を 健常人および結核症患者のそれと比較し た。測定方法としては, 充分に信頼性が認められまた安 価な PVF を用いた。採血条件については午前中は20〜 $25^{\circ} \mathrm{C}$ の環境気温で30 60分間の安静によって 基礎条件 に回復できるが, 高温環境では当条件の安静で回復でき ない。末梢組織のサイロキシンを消費させる要因たとえ ば日常生活動作は摂取率を低下させる。それゆえ早朝基 礎条件に回復せしめて採血した。なおチ才尿素丳は甲状 腺蛋白の硫黄との間に disulfide 結合を生じることが推 測され10a)，機能低下を招くと考えられるので測定例か ら除外した。その結果を像11に示した。

像11から，らい症状進行にともない，健常人に較べて 幾分かの機能低下の傾向が認められた。また 2 例の ENL 患者はかなり著明な機能低下を示したのに反し，3例の E.C.R. 患者は著るしい高值を示した。しかしスポンヂ
法による測定は， $\mathrm{T}_{3}$ 結合蛋白である Albumin, intra $\alpha \mathrm{G}$ のレベルが，らい患者においても平常人と大差が無 いという仮定下にはじめて成立する。もし $\mathrm{T}_{3}$ 結合蛋白 が增減すれば，その原因が甲状腺機能に由因するしない にかかわりなく，それぞれ摂取率は低下または増大す る。らい患者の血清蛋白変動がこれら要因と無関係か否 かは論議の余地がある。最近の報告で人血清 Thyroxine Bound Protein (TBG) が単離され, その性状も解明さ れつつあるから ${ }^{10 b)}$, 患者血清についての研究進展と相 まっていずれ解決されることが望まれる。なお像11のよ うに, 当該方法で測定した限りでは, 結核症患者に沖甲 状腺機能変動が認められなかった。

\section{討}

以上の各種実験成績から, 甲状腺機能検查法として検 討した PVF 法がなお種々改善の余地があるとしても， PBI 法とともに充分に臨床検査法として用いるに足る 測定法であることを認め，かつこれを用いてらい患者の 甲状腺機能を測定した結果, 軽症の病型の患者ほど序々 にではあるが甲状腺機能が改善されている結果を得た。

これがいかなる意味を持つかについて，らい病像と甲 状腺機能との関係に立って論じる場合に, ( ( ) $\mathrm{I}^{-} \rightarrow \mathrm{I}_{2} \rightarrow$ Thyroglobulin チロヂン残基ヨード化系路に関与する甲 
状腺顆粒内 peroxidase ${ }^{10 c)}$ や甲状腺ホルモンの Thyroglobulin からの水解系路, (口) TBG 量変動の有無との 関係およびこれらとや㨽腎皮質機能と ENL 発生との相 関点との関係が論点として考えられる。さらに E Epithelioid Cell Reaktion E.C.R. の位㯰, および(杖らい における甲状腺の意味を考えたい。

（亿）についてはまずらい患者の甲状腺自体の病変につ いて述べたい。宗内 ${ }^{1 a}$ はその病変は僅微で顕微鏡的のも のに過ぎないとしているが，最近佐々木ら ${ }^{11 a)}$ はアミロ イド甲状腺腫を 2 例のらい患者で認め，1 例はいわゆる 難治らい，ほかの1 例は敗血症により死亡した例であっ た。その際アミロイド変性特に dense な沈着が間質に 認められ，濾胞の圧迫萎縮が見られたとしている。また 古田はらい患者甲状腺への蓚酸沈着を認めた ${ }^{11 b) 。 ~}$

また従来, Thyroglobulin から水解されたホルモンの 脱ヨードは還元的反応だとされて来たが11c)，末梢では 酸化的脱ヨード反応であるとし, 証拠として catalase による阻害を挙げた報告もある11d)。このように甲状腺 ならびに末梢での酸化還元系が甲状腺ホルモンの role に微妙に関与するとすれば，らい患者甲状腺の病変およ び末梢各組織の病変がどのように影響しているのであろ うか。甲状腺病変が僅微であるとしてもその影響を無視 できない。またらい患者の末梢組織には著るしい病変が あり，たとえば皮膚機能の酸化還元系に大きな異態のあ ることについては波多 ${ }^{12 \mathrm{a})}$, 谷奥12b)，武田 ${ }^{3 \mathrm{e})}$ ，らの報告 の通りである。したがって肝そのほかの各重要臟器にお ける当該系の減弱もまた当然考えられるところであり， 重症な病型ほど甲状腺機能の減弱が思惟しうるところで ある。

(口) についてらい患者の TBG がどうなっているか は末明であるけれども, L型患者における $\gamma \mathrm{G}$ の増加, ENL 患者での $\alpha_{1}, \alpha_{2}-\mathrm{G}$ 増加は著るしい。らい病変に よりもしらい患者血清の intra- $\alpha$ 分画の増加があるとす れば，それは単にスポンヂ法による摂取率を見かけ上は 低下させているのではないかというような疑念以上に， らい患者の甲状腺機能はこの面からその機能障害を検討 されねばならないと考えられる。

ところがとyに関連ある興味深い研究として, 甲状腺ホ ルモンと副腎皮質ホルモンとの関係を論じた報告に，後 者が血清中 TBG を減少させたという結果を見ること

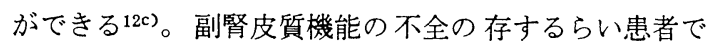
は13)，TBG を抑制する因子が少ないことが考えられ， 甲状腺機能ならびに基礎代謝低下と一致する。(1)，(口)の
影響が大きいと思われる ENL では殊に副腎皮質機能が たとえ一時的に六進したとしても，直ちに機能低下へ向 う傾向が強いと考えられる。特に ENL 発症直前には $\mathrm{Na}^{+}$の尿中排泄著増とともに尿中17-OH Corticosterone の排泄著減があり (八木, 大沢 $\left.{ }^{13}\right)$, 同時に 基礎代謝も -20\%にも低下してのち ENL を発症する時期がある。 これは ENL が副腎機能不全による適応能の不全から発 生するとする説14a,b)を証明するもので, ENL 発生值前 には著るしい副腎不全と甲状腺機能低下が存することを 明らかにしている。このような抗体産生抑制機序が減弱 している時期に無機ヨードを投与することは, いわゆる Wolff-Chaikoff 効果に則り, 甲状腺機能障害を加速す るのみか, 末梢細胞への刺戟誘発の因になり, 適応不全 に続いて ENL 発症に至る可能性も考えられ, 従前言わ れている無機ヨードによる ENL 誘発機作の説明として 今後の究明課題である。

ところが以上L型 ENL およびT型を含めてその甲状 腺機能および基礎代謝はすべて 低下傾向をもっている がここに(二に採り上げる E.C.R. のみにおいては未だ 少数例であるが高值を採る傾向が強く，八木の基礎代謝 による長期観察の例では50才 (男子) でありながら40 50 $\mathrm{Kcal} / \mathrm{m}^{2} /$ 時にまで達し, それは児童なみの代謝亢進に相 当し,これを以て疾病の治㾑経過にともなう二次的現象 と解するには困難があり,むしろ疾病を治癒に向わしめ る同化的代謝六進の意味14a) もあると解したい。さらに 結核家鬼に Thyroxine を与えて, その組織抵抗性を証 明したLurrie ら ${ }^{15 a)}$ の成績, さらに鼠らい発症防止実験 において Methimazole や放射性ヨードに比して $T_{3}$ の 効果が大きいことを報じた報告15b)を考えれば，L型ら い患者の治瘾機転の一つである E.C.R. において甲状腺 機能成績および基礎代謝值の亢進傾向のあることは，ら い治癒機作における甲状腺ホルモンの意味を示している と考えられる。しかし Methimazole, Tapazole などの 抗甲状腺剤では治らい効果は無いとされており16a-f), 抗 菌作用と甲状腺機能との間に複雑な関係の存することを 暗示していると考える。もちろん Ciba 1906における抗 甲状腺作用は, 当該薬物を抗抗酸菌作用の面で評価する ことに比すべきではないが，薬物作用機序から考えれ ば, 論点が存すると思える。以上の考察から, 甲状腺ホ ルモンが治らい機転において何らかの積極的な治癒機作 に関与しているらしいことは注目するとして，果してそ れが，化学療法剤による治瘁機転にどのように，どの程 度に関与していくかははなはだ興味ある問題であり，化 
学療法剤使用に当って, これらホルモン機能の変動を併 せ長期観察すべきことが痛感される。またこれら長期観 察はある程度動物実験によっても追跡しらるであろう。 また単なる抗菌作用のみでは説明しがたいところの化学 療法剤に対するらいにおける缩主感受性を考える時に, これら研究が, より有効な治らい方法, 治らい薬の出現 に益する可能性を感ぜしめる。特にらいにおけるG変動 と TBG の消長に関する血清免疫学的研究などの 基礎 資料を得ることは, 今後の化学療法に益すること多しと 思う。

本研究に当り，種々御卓見給わった東京警察病院稲垣 克彦博士，患者の採血試験提供に多大の御便宜を給わ。 た国立療殶所多磨全生園砏省吾医官, 新井正男医官なら びに血液を提供してくださった患者諸氏その他の協力者 に深甚なる謝意を表する。

本報文要旨は第16回日本癩学会東部地方会(昭和42年) に打いて発表した。

\section{参考文献}

1) 宗内敏男：レプラ, $5: 59(1934)^{\text {a) }}$; 竹内仁幸 : Ibid., $18: 17(1949)^{\mathrm{b})}$; Sehgal, V. N. et al. : Int. J. Lep., 35 : $58(1969)^{\mathrm{c})}$; Sister Ross, H. : Lep. in India, $36: 93(1969)^{d)}$.

2) 青木大勇 : 皮性誌，25: $724(1925)^{2)}$ ； I dem : Ibid., $30: 213(1930)^{\text {b) }}$; 山本悼二 : Ibid., 8 :

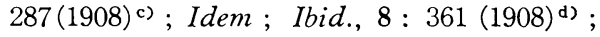
Muir, E. : Klingmüller, V., Ergebnisse der Lepraforschung, p. 91(1931)e) ; Gomez, J. M. et al.: Ibid., p. $\left.92(1930)^{\mathrm{f}}\right)$; Perewodtschikow, J. N. et al.: Ibid., p. 92(1930) ${ }^{\mathrm{g}}$.

3) Marras, A. et al.: Derm. \& Syph., 72 : $411(1931)^{\text {a) }}$; Moraes, Jr., J. Rev. Brazil Leprol., 5 : $287(1937)^{\text {b) }}$; Sister Ross, H. : Int. J. Lep., $8: 53(1940)^{c)}$; 井口清 : レプラ, 15 : $78(1943)^{\text {d) }}$; 武田己広 : Ibid., $26: 128(1957)^{\mathrm{e})}$; 宇都宮貞俊与：Ibid., 24 : 1(1955) f) ; 八木五 夫：体研報, 11: 407(1961) ${ }^{\text {g) }}$; 清水視学 : Ibid., $11: 513(1961)^{\mathrm{h}}$.

4）八木五夫：体研報, $11: 414$ (1961).

5) Inagaki, K.: Yokohama Med. Bulletin, 16 : 247 (1965)

6) Hamolsky, M. W. : J. Clin. Invest., 34 : $914(1955)^{\text {a) }}$; 中島博徳ら：内分泌之代謝, 3 : $61(1962)^{\text {b })}$; Idem : ホルモンと臨床，10：65 $(1962)^{b)}$.

7) Volpert, E. M. et al.: J. Clin. Endocrinol., \& Metabol., 27 : 421(1967)., Schussler, G. C. et al.: Ibid., $27: 242(1967)^{\text {a) }}$; 小屋佐久 次印：日本薬学会第88年会, 分析 $6 \mathrm{H} 5-1(1968)^{\mathrm{b}}$; Bowden, C. H. et al.: Biochem. J., $59: 93$ $(1955)^{c)}$; 裹良一：日本内分泌誌，41：860 $(1966)^{\text {d) }}$; Schwartz, H. L. et al.: Endocrinol., $80: 65(1967)^{\mathrm{e}}$.

8）稲垣克彦占：私信.

9) Clark, F. et al.: J. Clin. Endocrinol. \& Metabol., $27: 153(1967)^{\text {a) }}$; Lindahl, U.: $B$. B. Acta, $130: 368(1966)^{\text {b) }}$; Rohrs, H. C. et al.: Proc. Soc. Exp. Biol. Med., 124 : 645 $(1967)^{c)}$

10) Maloof, F. et al.: J. B. C., 236: 1689 $(1961)^{\text {a) }}$; Giorgio, Jr., N. A., et al.: Ibid., $243: 2247(1968)^{\text {b) }}$; Hosoya, T. et al.: Biochem. Biophy. Res. Commun., 20 : 27 (1965).

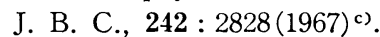

11）佐々木紀典5：第58回日本病理学会総会 $(1969)^{\text {a) }}$; 古田睦広ら：第41回日本癩学会総会 $(1968)^{\text {b) }}$; Stanbury, J. B. et al. : J. B. C., 228 : 801 (1957)., Ibid., 233 : 106(1958)., 湯 浅茂ら：生化学, $37: 619(1965)^{c)}$; Galton, V. A. et al.: Endocrinol., $73: 596(1963)^{d)}$.

12) 波多 治: レプラ, 21: $157(1952)^{a)}$, 谷奥喜 平 : 皮性誌, $63: 403(1953)^{b)}$; 加藤康二 : 日内 分泌誌, $42: 1048(1966)^{\mathrm{c}}$.

13）八木五夫・大沢佳子：レプラ, 35:263(1966).

14) Muir, E. : Lep. Rev., $33: 240(1962)^{\text {a) }}$; Schneck, R. : Leprosy in Theory and Practice, p. 202, 342(1962) b) ; 緒方維弘・鉿江懐 : 結核 と癩の生理および病理, 2-11(1955) c).

15) Lurie, M. B. et al.: Am. Rev. Tuberc., 79 : $152(1959)^{\text {a) }}$; Gutierrez, R. : Lep. Rev., 38 : $31(1967)^{b}$.

16) Levy, L., et al. : Int. J. Lep., 35 : 149 $(1967)^{\text {a) }}$; O'Byrne, A. : Ibid., 28: 401 $(1960)^{\text {b) }}$; Davison, A. R. : Ibid., $31: 9$

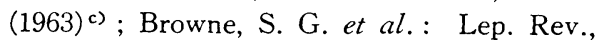
$33: 190(1962)^{\text {d) }}$; Rojas, B. : Ibid., $34: 203$ $(1963)^{\text {e) }}$; Ramanujam, K. : Lep. in India, $35: 3(1963)^{f}$. 